\title{
A study of the parasitoid complex of the European fir budworm, Choristoneura murinana (Lepidoptera: Tortricidae), and its relevance for biological control of related hosts
}

\author{
N.J. Mills \\ Division of Biological Control, University of California, USA \\ M. Kenis \\ IIBC European Station, Delémont, CH-2800, Switzerland
}

\begin{abstract}
The parasitoid complex and apparent parasitism of Choristoneura murinana Hübner were investigated in relation to the relative abundance of budworm larvae at several sites in Europe. A single outbreak population was sampled, while other sites supported varying but much lower host population abundance. Sampling at Sion in Switzerland from 1984-89, indicated that the species richness of the parasitoid complex was correlated with relative host abundance and in general more polyphagous parasitoids were represented in sites with greater budworm abundance. Of the specialized parasitoids, Apanteles murinanae Capek \& Zwölfer (Hymenoptera: Braconidae) was dominant in less abundant host populations and both Cephaloglypta murinanae (Bauer) and Dirophanes maculicornis (Stephens) (Hymenoptera: Ichneumonidae) were supported only at greater budworm abundance. These findings are discussed in relation to the use of Choristoneura murinana parasitoids in the biological control of native Choristoneura spp. pests in other continents.
\end{abstract}

\section{Introduction}

The Holarctic genus Choristoneura comprises leafrolling tortricids that feed on the foliage of trees, mostly conifers. These leaf-rollers are among the most destructive of forest insect pests in temperate forests. The Nearctic Region supports many species of which the eastern spruce budworm, C. fumiferana (Clemens) defoliating spruce and fir (Sanders et al., 1985), and the western spruce budworm, $C$. occidentalis Freeman defoliating Douglas fir and true firs (Brookes et al., 1987), are the most widespread and damaging. In the Palaearctic Region, C. murinana attacks silver fir in Europe (Bogenschütz, 1978a), C. diversana Hübner attacks Todo-fir

Correspondence: N.J. Mills, Division of Biological Controi, University of California, 1050 San Pablo Ave, Albany CA 94706, USA. in Japan (Suzuki, 1981) and C. metasequoiacola Liu is a common pest of redwoods in China (Xu \& Liao, 1985).

Choristoneura species are indigenous pests that have fortunately not spread from their primary regions of distribution. Control measures have frequently been required and have largely been based on the use of chemical insecticides. Experience from North America has shown, however, that after 35 years of operational spraying the control achieved serves only to protect the current year's foliage and does nothing to bring about the collapse of outbreak populations (Armstrong, 1985). More recently, through increasing public concern for the degradation of the environment, alternative controls have been sought. The two main alternatives are silvicultural control (Carlson et al., 1985) and biological control (Mills, 1983). In contrast to the prophylactic insecticide control, both alternative approaches can offer longerterm remedial solutions to the Choristoneura problems but inevitably require further research and development. 
Classical biological control of $C$. fumiferana in Canada, through the importation and release of exotic parasitoids from related hosts from other geographic regions, was first attempted in the 1940s and early 1950 s (Mills, 1983). Parasitoids were collected from both C. occidentalis in British Columbia and $C$. murinana in France and Germany and were released in eastern Canada. Unfortunately, none of the parasitoids became established and no control was achieved. The introductions were carried out, however, at a time in the history of biological control when collection and release were considered the only requirements for success in classical biological control. Consequently there was little documentation of the releases making it impossible to assess objectively the further potential for biological control (Mills, 1983).

In 1983, Forestry Canada in collaboration with the $\mathrm{CAB}$ International Institute of Biological Control (now the International Institute of Biological Control - IIBC) started a new programme of parasitoid importations against $C$. fumiferana and to evaluate more critically the compatibility of the new parasitoid-host interactions before releasing parasitoids for budworm control. This paper summarizes the observations made on the larval and pupal parasitoids of $C$. murinana in France, Switzerland and Poland during parasitoid collections for the Canadian biological control programme.

C. murinana, is a central European species that has sporadic outbreaks on silver fir, Abies alba, that are generally of short duration (Bogenschütz, 1978a). The budworm is univoltine with a flight period in July and early August. Eggs are laid in batches on the needles and the larvae hatch in late summer, dispersing on silken threads. Once settled the first instar larvae spin overwintering hibernacula under bark scales at the base of twigs in the upper crown of the fir trees. In the hibernacula, the larvae moult to the second instar before entering diapause. The larvae re-emerge from hibernacula towards the end of April and feed on the developing shoots through to the sixth instar. Pupation occurs in rolled shoots at the larval feeding sites in June.

\section{Methods \\ Field sites}

Parasitoid surveys and collections were made at two sites in France, St Bonnet (Ardèche) at the eastern edge of the Massif Central from 1983-1985, and Guebwiller at the eastern edge of the Vosges Mountains in 1990. In Switzerland, collections were made at Sion (Valais) in the Rhone valley from 1984-1989 and at Visp (Valais) in 1990. In Poland, a small collection was made at St Katarzyna in the Swietokrzyskie mountains in 1985.

At St Bonnet, the site comprised a small stand of approximately 100 ha of mature fir that was surrounded by spruce forest (see Géraud et al., 1987 for further details). The site, at an elevation of $800-1000 \mathrm{~m}$, has no history of budworm outbreaks but population densities of C. murinana larvae began to increase around 1980 and reached a level that caused a limited extent of defoliation in 1985 (Cornic et al., 1987). The C. murinana population in 1986 was controlled by treatment with Bacillus thuringiensis

At Guebwiller, the site comprised approximately 100 ha of mature fir at 500-700 m elevation which forms part of a larger forest region of the Vosges Mountains. A budworm outbreak occurred in this region in the mid1950 s with 4800 ha affected and defoliation began again in 1989 affecting about 600 ha in 1990.

The sites at Sion and Visp, as at St Bonnet, comprised small and isolated pockets of mature fir. The stands were 20-50 ha of mixed silver fir and spruce, and also included hardwood species at Visp. The Sion site has an elevation of $800-1000 \mathrm{~m}$, while that at Visp was at $1000-1200 \mathrm{~m}$. These sites have no history of budworm outbreaks and the populations sampled never reached severely defoliating densities. At both sites, the fir budmoth Zeiraphera rufimitrana (Schiffermüller) was also present. C. murinana was first noted in 1983 in Sion and 1989 in Visp. The Sion population reached a peak in 1986 and had declined to very low levels by 1990 .

St Katarzyna at $600-800 \mathrm{~m}$ is a site of mixed fir spruce, beech and oak forest in a larger forested region of the Swietokrzyskie mountains (Wiackowski, 1984). Budworm outbreaks have been frequent at this site, the last outbreak having occurred in the mid 1970s. Some nearby stands were treated with insecticides in 1985, although the collection site showed little sign of defoliation.

\section{Collections and rearing}

C. murinana larvae and pupae were collected from the foliage of the lower crown of mature silver fir using $8 \mathrm{~m}$ pole pruners to cut the lower branches. Hosts were also collected from the foliage of understory trees. The larvae collected at St Bonnet were from a single sample each year made between 17-23 June. The collection from St Katarzyna was similarly a single sample made on 14 June. From Guebwiller in 1990, four samples were collected between 22 May and 6 June and from Visp, three samples were collected between 8 and 22 June.

At Sion, three consecutive samples were taken from early to late June at approximately weekly intervals from 1984-1989. In 1986 and 1987, the peak years of budworm abundance at Sion, densities of larvae in the lower canopy of the mature firs were estimated from $2 \mathrm{~m}$ length branch samples. In 1988 and 1989, the collected larvae were visually separated by instar into $L_{3 / 4}, L_{5}$ and $\mathrm{L}_{6}$ to estimate the stage from which parasitoids emerged.

In general budworm abundance was low and density estimates were too impractical to obtain. A measure of the relative abundance of the budworm was obtained by determining the number of larvae collected per manhour for each site and year.

In all cases the larvae and pupae were collected into gauze bags and taken back to the laboratory where they were placed individually on cut foliage in plastic tubes $(54 \times 27 \mathrm{~mm})$. The tubes were closed with foam rubber stoppers which were moistened daily to prevent the foliage from drying out. The foliage was renewed twice each week until the hosts pupated or died. Apparent percentage parasitism was estimated from the total number of parasitoids reared for each site and year in relation to the total number of hosts either parasitized or successfully reared to the next life stage. 
Table 1. The parasitoid complex and number of parasitoids reared from C. murinana at Sion in the Swiss Valais from 1984-1989. Relative host abundance represents the number of host larvae collected per man-hour.

\begin{tabular}{|c|c|c|c|c|c|c|}
\hline Year & 1984 & 1985 & 1986 & 1987 & 1988 & 1989 \\
\hline \multicolumn{7}{|l|}{ Larval parasitoids } \\
\hline Relative host abundance & 18 & 28 & 42 & 36 & 29 & 16 \\
\hline Number of hosts reared & 98 & 1439 & 2601 & 2408 & 1937 & 1370 \\
\hline$\%$ apparent larval parasitism & 15 & 7 & 10 & 10 & 14 & 8 \\
\hline \multicolumn{7}{|l|}{ Ichneumonidae } \\
\hline Apophua bipunctorius (Thunberg) & & 2 & 3 & 5 & & 1 \\
\hline Campoplex rufinator (Aubert) & & 3 & & 2 & & 1 \\
\hline Cephaloglypta murinanae (Bauer) & & & & & 1 & \\
\hline Chorinaeus funebris (Gravenhorst) & 1 & & & & & \\
\hline Enytus montanus (Ashmead) & & 1 & 3 & 12 & 7 & 3 \\
\hline Habronyx nigricornis (Wesmael) & & 3 & & & & \\
\hline Lissonota folii (Thomson) & & & 2 & & & \\
\hline Phytodietus arcuatorius (Thunberg) & & & & 2 & 1 & \\
\hline Scambus buolianae (Hartig) & & & 1 & & & \\
\hline Scambus calobatus (Gravenhorst) & 1 & & 1 & & & \\
\hline Tranosema rostrale (Brischke) & 7 & 1 & 5 & 5 & 5 & 12 \\
\hline Triclistus globulipes (Desvignes) & & & 2 & & 2 & \\
\hline \multicolumn{7}{|l|}{ Braconidae } \\
\hline Apanteles murinanae (Capek \& Zwölfer) & 1 & 82 & 213 & 200 & 258 & 98 \\
\hline Charmon extensor (Linnaeus) & & & & & 1 & \\
\hline Meteorus ictericus (Nees) & & 2 & 16 & & & \\
\hline Oncophanes laevigatus (Ratzeburg) & 2 & & & 1 & & 1 \\
\hline \multicolumn{7}{|l|}{ Bethylidae } \\
\hline Goniozus sp. & & & 1 & & & \\
\hline \multicolumn{7}{|l|}{ Tachinidae } \\
\hline Actia maksymovi Mesnil & 3 & & 2 & 5 & & \\
\hline Nemorilla maculosa (Meigen) & & 4 & 23 & 6 & 3 & \\
\hline \multicolumn{7}{|l|}{ Pupal parasitoids } \\
\hline Number of hosts reared & 22 & 130 & 147 & 68 & 0 & 0 \\
\hline$\%$ apparent pupal parasitism & 5 & 15 & 31 & 22 & & \\
\hline \multicolumn{7}{|l|}{ Ichneumonidae } \\
\hline Apechthis quadridentatus (Thomson) & 1 & 7 & 7 & 7 & & \\
\hline Itoplectis maculator (Fabricius) & & 12 & 38 & 8 & & \\
\hline
\end{tabular}

\section{Results}

Parasitism of C. murinana at Sion

The larval and pupal parasitoids reared from C. murinana collected over a six year period near Sion in the Swiss Valais are presented in table 1.

The host populations at this site were relatively low and initial attempts to determine the density of larvae in the very tall fir canopies were abandoned due to logistical problems. In place of density estimates, relative abundance was estimated from the number of larvae that were collected per man-hour (table 1). Only in the peak years of abundance in 1986 and 1987 could meaningful estimates of budworm density be obtained. The mean densities of larvae in the lower canopy of the mature fir trees, estimated from branch samples, were 0.69 larvae per metre length of branch in $1986(n=35, \mathrm{SD}=1.18)$ and 0.49 larvae per metre in $1987(n=37, \mathrm{SD}=0.88)$. This corresponded to a relative abundance of 42 and 36 larvae per man-hour of collecting for the same two years. The rela- tive abundance of budworm in the lower canopy and understory is clearly not linearly related to the density of budworm larvae in the lower canopy, as a zero density would be obtained from a relative abundance of 21 larvae per man-hour by extrapolation. However, relative abundance is a useful comparative estimate that can be used to compare parasitism across years and sites.

Only two parasitoids, the ichneumonid Tranosema rostrale (Brischke) and the braconid Apanteles murinanae (Capek \& Zwölfer) were consistently found each year. Many of the parasitoids were reared only from a single host individual over the six year period, including the ichneumonids Cephaloglypta murinanae (Bauer), Chorinaeus funebris (Gravenhorst) and Scambus buolianae Hartig, the braconid Charmon extensor (Linnaeus) and the bethylid Goniozus sp. The other parasitoids occurred erratically but always in relatively small numbers. The rates of apparent larval parasitism varied from $7 \%$ in 1985 to $15 \%$ in 1984. Apparent pupal parasitism was a little more extensive at $5-31 \%$ over the period $1984-87$. 


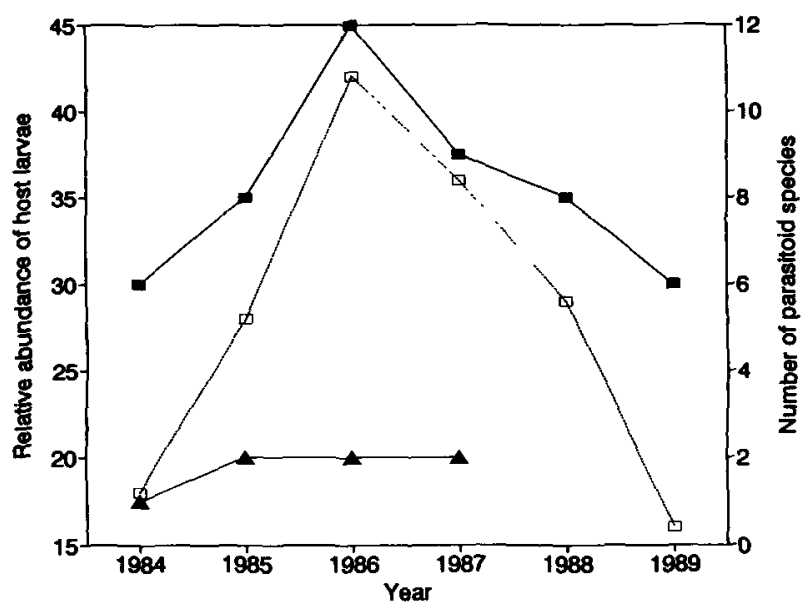

Fig. 1. The species richness of the parasitoid complex of Choristoneura murinana at Sion, Switzerland in relation to the relative abundance of host larvae. Larval parasitoid species $(-\longrightarrow)$, pupal parasitoid species $(-\boldsymbol{\downarrow})$, and host abundance, larvae collected per man-hour (... $\square$...).

The species richness of the sampled parasitoid complex varied from seven species in 1984 to 14 species in the peak year of 1986. In fact the species richness of larval parasitoids is well correlated (Kendall's $\tau=0.93, P$ $=0.05$ ) with the relative abundance of the budworm larvae (fig. 1). The difference in species richness is probably due to an increased number of incidental parasitoids that attacked Choristoneura murinana during its peak years of abundance. Thus in 1986 there were three additional less-specialized larval parasitoid species that were not reared in any other year. It remains possible, however, that this is a sampling artefact in that the larger the sample collected (i.e. in the peak years of abundance), the greater the probability of including the rarer species in a parasitoid complex.

The most abundant of the parasitoids reared from $C$. murinana at Sion was the braconid $A$. murinanae. This was the only species on which more detailed observations could be made. Host larval collections in 1988 and 1989 indicate that the apparent parasitism of $C$. murinana declined with host age, as determined by host instar at the time of collection (fig. 2). The third and fourth instars $\left(\mathrm{L}_{3 / 4}\right)$ formed only $9 \%$ of the larvae collected, but of these apparent parasitism averaged $52 \%$, while sixth instar larvae comprised $60 \%$ of the host larvae sampled and for which apparent parasitism was $2 \%$. The sharp drop in apparent parasitism from $L_{3 / 4}$ to $L_{6}$ is probably artificial. Parasitism of Choristoneura pinus Freeman by Apanteles fumiferanae Viereck prolongs the duration of the earlier host instars (Nealis, 1987) and it is likely that the apparent parasitism for $L_{3 / 4}$ (and to a lesser extent $L_{5}$ ) was elevated due to nonparasitized individuals having already developed to the subsequent instars at the time of the field collections. The data suggest, however, that at least part of the drop in apparent parasitism may be due to $A$. murinanae killing and emerging from fourth instar hosts. The data are in fact consistent with $A$. murinanae emergence from fourth, fifth and sixth instar host larvae, although this is confounded by the prolonged development of parasitized hosts.

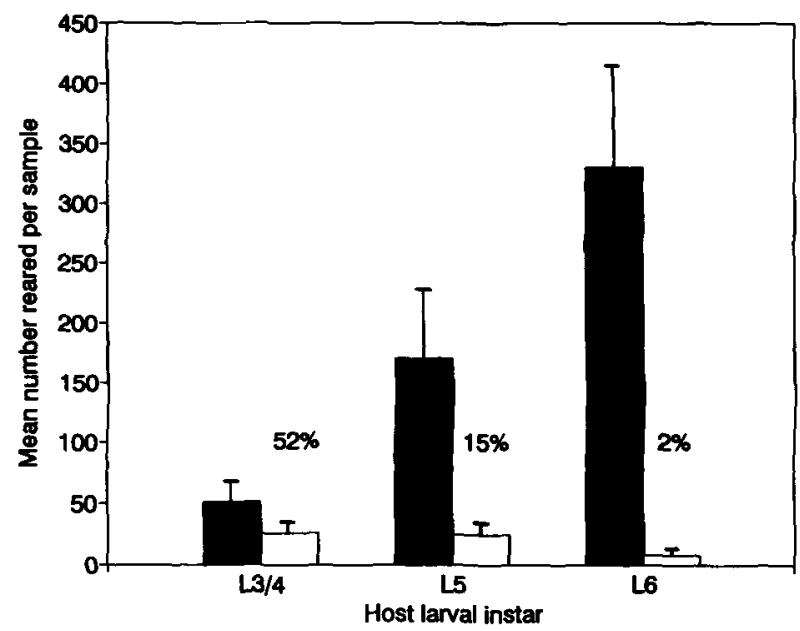

Fig. 2. Parasitism of Choristoneura murinana by Apanteles murinanae at Sion, Switzerland from 1988-89 in relation to host larval instar. Mean hosts reared $\mathbf{0}$, mean $D$. petrovae reared $\square$ and percentage parasitism ( $n=6$, bars $=$ s.e.).

The apparent percentage parasitism of the C. murinana larvae collected at Sion increased from 1984 to 1988, and fell only in 1989 the last year of sampling, despite the host population's peaking in abundance in 1986 (fig. 3 ). This lag effect of parasitism is typical of univoltine insect parasitoids although in this case the lag extends over two host generations.

It is interesting to note that there was very little overlap between the parasitoids of Zeiraphera rufimitrana and $C$. murinana at this site. The larval parasitoid complex of $Z$. rufimitrana was very restricted (Mills, unpublished) and was dominated by Apanteles lineipes (Wesmael). However, on no occasion was A. lineipes reared from $C$. murinana and the only parasitoid species to attack both hosts was the ichneumonid, Enytus montanus (Ashmead)

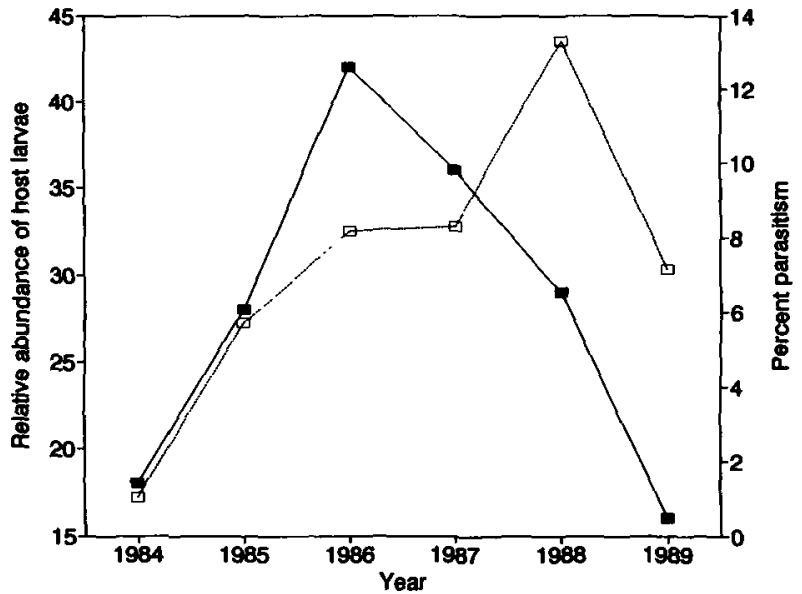

Fig. 3. Parasitism of Choristoneura murinana by Apanteles murinanae at Sion, Switzerland in relation to relative host abundance. Host abundance, larvae collected per man-hour $(--)$ and percentage apparent parasitism $(-[-\square)$. 
Table 2. The parasitoid complex and number of parasitoids reared from $C$. murinana in France, Poland and Switzerland between 1983 and 1990. Relative host abundance represents the number of host larvae collected per man-hour (*not appropriate for outbreak densities).

\begin{tabular}{|c|c|c|c|c|c|c|}
\hline \multirow{2}{*}{$\begin{array}{l}\text { Site } \\
\text { Year }\end{array}$} & \multicolumn{3}{|c|}{ St Bonnet } & \multirow{2}{*}{$\begin{array}{c}\text { Guebwiller } \\
1990\end{array}$} & \multirow{2}{*}{$\begin{array}{c}\text { St Katarzyna } \\
1985\end{array}$} & \multirow{2}{*}{$\begin{array}{l}\text { Visp } \\
1990\end{array}$} \\
\hline & 1983 & 1984 & 1985 & & & \\
\hline \multicolumn{7}{|l|}{ Larval parasitoids } \\
\hline Relative host abundance & 13 & 17 & 25 & * & 101 & 90 \\
\hline Number of hosts reared & 138 & 319 & 507 & 3018 & 202 & 1783 \\
\hline$\%$ apparent larval parasitism & 17 & 4 & 12 & 33 & 19 & 18 \\
\hline \multicolumn{7}{|l|}{ Ichneumonidae } \\
\hline Agrypon varitarsum (Wesmael) & & & & 1 & & \\
\hline Apophua bipunctorius (Thunberg) & & & 2 & 47 & 1 & \\
\hline Campoplex rufinator (Aubert) & & & & 2 & & \\
\hline Cephaloglypta murinanae (Bauer) & 5 & & 2 & $91 \overline{7}$ & 5 & 207 \\
\hline Chorinaeus longicornis (Thomson) & & & & 1 & & \\
\hline Enytus montanus (Ashmead) & & & & & & 2 \\
\hline Habronyx nigricornis Wesmael & 2 & & & 1 & 1 & \\
\hline Phytodietus segmentator Gravenhorst & & & & & 7 & 1 \\
\hline Tranosema rostrale (Brischke) & 1 & 3 & 8 & 3 & 2 & 25 \\
\hline Triclistus globulipes (Desvignes) & & & & & 1 & 1 \\
\hline \multicolumn{7}{|l|}{ Braconidae } \\
\hline Apanteles murinanae (Čapek \& Zwölfer) & 5 & 7 & 23 & 3 & & 69 \\
\hline Charmon extensor (Linnaeus) & & & & 4 & & 3 \\
\hline Meteorus ictericus (Nees) & 2 & & 2 & 4 & 19 & 4 \\
\hline Oncophanes laevigatus (Ratzeburg) & & 1 & & & 1 & \\
\hline Pygostolus sticticus (Fabricius) & & 1 & & & & \\
\hline \multicolumn{7}{|l|}{ Tachinidae } \\
\hline Actia maksymovi Mesnil & 8 & & 11 & & & 1 \\
\hline Nemorilla maculosa (Meigen) & 1 & & 13 & & 1 & \\
\hline Unidentified species & & & & 13 & & \\
\hline \multicolumn{7}{|l|}{ Pupal parasitoids } \\
\hline Number of hosts reared & 67 & 0 & 0 & 357 & 83 & 41 \\
\hline$\%$ apparent pupal parasitism & 12 & & & 37 & 31 & 29 \\
\hline \multicolumn{7}{|l|}{ Ichneumonidae } \\
\hline Apechthis quadridentatus (Thomson) & 6 & & & 32 & 14 & 3 \\
\hline Apechthis rufatus (Gmelin) & 2 & & & 1 & 10 & 2 \\
\hline Itoplectis maculator (Fabricius) & & & & 45 & 2 & 4 \\
\hline Dirophanes maculicornis Stephens & & & & 50 & & 3 \\
\hline Pimpla turionellae Linnaeus & & & & 1 & & \\
\hline
\end{tabular}

Parasitism of C. murinana at other sites

The species richness of the parasitoid complex found at St Bonnet in the Ardèche from 1983 to 1985 (table 2) was similar to that found at Sion. In general, the abundance of $C$. murinana was lower than at Sion and the range of occasional parasitoids was reduced. As in Sion, A. murinanae was the dominant parasitoid in terms of constancy and numbers reared. While relative host abundance increased over the sample period, both total larval parasitism and that due to $A$. murinanae showed no response. As at Sion, the ichneumonid Tranosema rostrale was also a constant parasitoid and this species did show a limited response to the increasing host abundance with apparent parasitism increasing from $0.7 \%$ to $1.6 \%$.

The larval and pupal parasitoid complexes found at St Katarzyna in Poland (table 2) were both more species rich than their counterparts at Sion and St Bonnet. Inter- estingly, A. murinanae was absent from the sample and tachinids were very poorly represented. Larval parasitism was dominated by the braconid Meteorus ictericus (Nees) and two ichneumonids Cephaloglypta murinanae and Phytodietus segmentator Gravenhorst, were recovered in appreciable numbers. Despite the few budworm larvae collected at this site, the relative abundance was in fact much higher than at Sion or St Bonnet as a result of the very low collection effort.

Parasitism of the budworm collected at Visp (table 2) differed considerably from that at Sion, despite these sites being separated by only about $50 \mathrm{~km}$ along the Rhone Valley. Parasitism by $A$. murinanae and Tranosema rostrale were similar to that at Sion but in contrast tachinid parasitism was poorly represented and Cephaloglypta murinanae was the most abundant larval parasitoid. The presence of $C$. murinanae and the poor representation of tachinid parasitism were also characteristic of St Katarzy- 
na in Poland, a site that had a similar relative abundance of budworm larvae. The range of pupal parasitoids found at Visp was also greater than that at Sion.

At Guebwiller, the abundance of Choristonera murinana was much greater that at any of the other sites and represented a typical outbreak. At these densities, the number of larvae collected per man-hour is determined more by ability to handle large numbers of larvae than to find them and so no longer represents relative abundance. The larval parasitoid complex (table 2) was dominated by Cephaloglypta murinanae. Parasitism by tachinids, A. murinanae and Tranosema rostrale was very limited. The species richness of the larval parasitoid complex and the pupal parasitoid complex found at this site were 12 and 5, respectively.

\section{Hyperparasitism}

Since host larvae were usually collected from the field before parasitoids had emerged from their hosts, no cocoon parasitoids were reared from the bulk of the samples. Parasitism by true hyperparasitoids, those that attack the host at an earlier stage of development, was less than $1 \%$ and due to Mesochorus spp. (Hymenoptera: Ichneumonidae). At Sion, $M$. macrurus Thomson was reared from Apanteles murinanae and $M$. sylvarum Curtis was reared from this same host at St Bonnet. However, parasitism of $A$. murinanae cocoons, collected in the field at Sion in 1986 and 1987, was more extensive $(52 \%, n=23)$ and exclusively due to the pteromalid Mesopolobus subfumatus (Ratzeburg).

\section{Discussion}

Mills (1983) has reviewed the parasitoid complex of Choristoneura murinana in central Europe (Bucher, 1953 and Zwölfer, 1956 (France), Franz, 1940, Bucher, 1953 and Zwölfer, 1961 (Germany), Capek, 1963 (Czechoslovakia), Schimitschek, 1936 (Austria), Gadek, 1984 and Wiackowski, 1984 (Poland)). In almost all cases these have concerned either samples from a single year or sporadic samples over longer time periods. Previous observations have also been almost exclusively confined to outbreak populations of the host. The present survey differs from those reported earlier in that it is primarily concerned with lower host density populations of C. $m u$ rinana rather than outbreaks, it provides longer term observations from individual field sites, and it provides at least some indication of the abundance of the host population at the time of sampling.

\section{Estimation of parasitoid complexes and parasitism}

In the present study, the parasitoid complex and the relative degree of apparent parasitism of $C$. murinana have been estimated from samples collected from the lower canopy and from understory trees. This sampling strategy was consistent between years and sites but may not be fully representative of parasitism throughout the forest canopy. Budworm larvae, however, drop through the canopy as they become larger and more active and this would have helped to reduce any vertical stratification of parasitism. Despite this, the data observed remain a small and limited sample of the total canopy population and may not be fully representative of the parasitoid complex and relative parasitism of $C$. murinana.

\section{Changes in the parasitoid complex with host abundance}

Many forest insects support parasitoid complexes that change in composition with host abundance (Mills, 1990). The current comparison of lower density and outbreak density populations of $C$. murinana indicates some important differences. It is clear, for example, that the more abundant the $C$. murinana population, the greater was the species richness of the parasitoid complex. The richness of the complex at Sion was directly correlated with the relative abundance of $C$. murinana while the richness of the parasitoid complexes at other sites also reflected differences in relative host abundance. The species richness increased in two ways, either by the addition of some more specific parasitoids or by the accumulation of incidental parasitoids.

Of the more specific parasitoids, the larval parasitoid Cephaloglypta murinanae and the pupal parasitoid Dirophanes maculicornis, were supported only at sites with greater host abundance and are perhaps representative of high host density specialists. These two parasitoids have also been well represented in the outbreak populations of Choristoneura murinana investigated by the majority of previous authors (see list above). In those cases where the representation of these two specialized parasitoids was not so apparent (e.g. Bogenschütz, 1978b; Capek, 1963), the absence of data on host abundance prevents a valid assessment of the outbreak status of the budworm populations sampled. At the lower host densities sampled in the current study, larval parasitism was dominated by $A$. murinanae and to a lesser extent by Tranosema rostrale and the tachinid Actia maksymovi. These parasitoids appear to be low density specialists, with little representation at the higher and outbreak host densities that occurred at St Katarzyna and Guebwiller. These same parasitoids were either absent or poorly represented in previous studies on outbreak host populations, although $A$. murinanae was dominant in the Czechoslovakian sites sampled by Capek (1963), again suggesting that these populations were perhaps not representative of true outbreaks. Only at Visp, which had an intermediate relative abundance of budworm, and perhaps also the Czechoslovakian sites of Čapek (1963) do we see the co-occurrence of both high and low density parasitoids.

There appear to be no specialist low density pupal parasitoids of $C$. murinana, with polyphagous parasitoids dominating parasitism at low host densities. Specialization at this stage of the host life cycle appears to be possible only in high density host populations.

Similar changes in the representation of specialist larval parasitoids in relation to host abundance are known from other conifer tortricids (Mills, 1990). The reason for the absence of high host density specialists from host populations at lower densities is not clear but could be the result of poor host searching ability of the parasitoids. The decline in representation of low host density specialists as host densities increase cannot be related to host searching ability but is more likely to be due to changes in micro-environment. For example, both 
micro-climate and the extent to which tortricid larvae can spin foliage into a protective roll will change as defoliation increases and either factor may disrupt host acceptance by a low host density parasitoid.

The second factor affecting the species richness of parasitoid complexes is the probable accumulation of incidental parasitoids at higher host densities. This is seen for larval parasitoids both at the peak abundance of the Sion population and at the higher population densities at Visp, St Katarzyna and Guebwiller. Almost all parasitoids respond to host or host-plant associated volatile odours (Vinson, 1986) and some cross attraction may result from the large quantity of volatile odours released by the feeding of abundant host larvae. The incidental parasitoids tend to be either polyphagous or specialized on other host species and are unable to attack the host successfully to any appreciable degree.

\section{Biological control potential}

It is clear that parasitoids are limited in their impact on $C$. murinana populations and are unable to prevent the budworm from causing outbreaks in fir forests in central Europe. The more specialist parasitoids include the larval parasitoids, A. murinanae, Cephaloglypta murinanae, and the pupal parasitoid Dirophanes maculicornis. As discussed above, A. murinanae appears most effective at low host densities but it experiences high levels of cocoon parasitism, estimated at up to $52 \%$ at Sion, that must severely limit its potential to respond to changing host densities. The other two specialist parasitoids are active only at higher host densities and during outbreaks. Their levels of parasitism can be extensive, 30\% for C. murinanae and $14 \%$ for D. maculicornis at Gueb willer, although $C$. murinanae has also been reported to suffer up to $45 \%$ hyperparasitism (Zwölfer, 1961). The other parasitoids reared from Choristoneura murinana are either bivoltine or multivoltine and thus unable to respond to changes in the abundance of $C$. murinana due to their dependence on alternate hosts to survive through the year.

From the biological control perspective, the only parasitoids of $C$. murinana which offer some potential as importations for the control of $C$. fumiferana in Canada are the three specialized species, in view of their specificity and independence from alternate hosts. Their inability to prevent outbreaks of $C$. murinana in Europe, however, is not indicative of their potential as imported biological control agents in North America. Two previous biological control programmes against forest insects in Canada, that of the winter moth (Operophtera brumata (Linnaeus) (Lepidoptera: Geometridae)) and the larch casebearer (Coleophora laricella (Hübner) (Lepidoptera: Coleophoridae)), have proved to be successful despite indications that the imported specialist parasitoids are unable to control their host populations in Europe (Dahlsten \& Mills, 1992).

Of the specialized European parasitoids only Cephaloglypta murinanae was released in northern Ontario during the previous biological control programme against Choristoneura fumiferana in the 1950 s and this attempt failed to establish the parasitoid. The releases, however, were restricted to a total of 593 individuals over three years, the largest single release being of 285 females at Aaron
Park in 1956 (McGugan \& Coppel, 1962). From Canadian experience of parasitoid importations, Beirne (1975) has argued that establishment is unlikely to be achieved if less than 5000 individuals of an imported natural enemy are released. We also do not know if Cephaloglypta murinanae can successfully attack Choristoneura fumiferana as a novel host. For these reasons the Cephaloglypta murinanae release in the 1950s cannot be considered a suitable test of the potential of this species.

In using exotic parasitoids for the control of native pests it is essential to verify the compatibility of the new parasitoid-host relationship before field releases are attempted. Any exotic parasitoid species that fails either to successfully oviposit or to complete its development on the target host in the laboratory cannot be considered compatible and must be excluded as a potential control agent. Laboratory studies have confirmed that $A$. murinanae is compatible with the target host, Choristoneura fumiferana, (V.G. Nealis, pers. comm.) and field releases of this European parasitoid commenced in Ontario in 1990. Laboratory trials are currently under way for Cephaloglypta murinanae and if compatible this species will also be field released against Choristoneura fumiferana.

\section{Acknowledgements}

We thank P. du Merle and F. Cornic for informing us of the field site in the Ardèche, M. Pitteloud for access to the field sites in Sion and Visp, K. Gadek for assistance in Poland and the French Département de la Santé des Forêts for indicating the outbreak at Guebwiller. We would also like to thank P. Aubert, E. Haeselbarth, B. Herting, K. Horstmann and $W$. Schwenke for determination of the parasitoid species, Forestry Canada for financial support and Vince Nealis and Michael Hulme for their comments on the manuscript. Voucher specimens are stored in the collections of the IIBC Station in Delémont.

\section{References}

Armstrong, J.A. (1985) Tactics and strategies for larval suppression and prevention of damage using chemical insecticides. pp. 301-319 in Sanders, C.J., Stark, R.W., Mullins, E.J. \& Murphy, J. (Eds) Recent advances in spruce budworm research. Ottawa, Canadian Forestry Service.

Beirne, B.P. (1975) Biological control attempts by introductions against pest insects in the field in Canada. Canadian Entomologist 107, 225-236.

Bogenschütz, H. (1978a) Tortricinae. pp. 55-89 in Die Forstschadlinge Europas. 3. Band. Schmetterlinge. Hamburg, Paul Parey.

Bogenschütz, H. (1978b) Über die Parasitierung der Puppen von Choristoneura murinana $\mathrm{Hb}$. (Lepidoptera, Tortricidae) im polischen Mittelgebirge. Zeitschrift für angewandte Entomologie 86, 294-307.

Brookes, M.H., Campbell, R.W., Colbert, J.J., Mitchell, R.G. \& Stark, R.W. (1987) Western spruce budworm. Technical Bulletin USDA Forest Service No. 1694, 198 pp.

Bucher, G.E. (1953) Biotic factors of control of the European fir budworm, C. murinana, in Europe. Canadian Journal of Agricultural Science 33, 448-469.

Čapek, M. (1963) Neuere Kenntnisse aus der Bionomie der Raupenparasiten von Choristoneura murinana $\mathrm{Hb}$. und Epinotia nigricana H.S. (Lep., Tortricidae). Zeitschrift für angewandte Entomologie 51, 137-141. 
Carlson, C.E., Fellin, D.G., Schmidt, W.C. \& Wulf, N.W. (1985) Silvicultural approaches to western spruce budworm management in the northern US Rocky Mountains. pp. 281-300 in Sanders, C.J., Stark, R.W., Mullins, E.J. \& Murphy, J. (Eds) Recent advances in spruce budworm research. Ottawa, Canadian Forestry Service.

Cornic, J.F., Géraud, D. \& du Merle, P. (1987) Observations sur la distribution spatiale et sur la mesure des populations pré-imaginales de la tordeuse du sapin. 2. Les populations larvaire et conclusion. Journal of Applied Entomology 103, 403-417.

Dahlsten, D.L. \& Mills, N.J. (in press) Biological control of forest insects. In Fisher, T.W. et al. (Eds) The principles and applications of biological control. University of California Press.

Franz, J. (1940) Der Tannentriebwickler Cacoecia murinana $\mathrm{Hb}$ Zeitschrift für angewandte Entomologie 27, 345-407, 485-620.

Gadek, K. (1984) Role of useful entomophages in limitation of mass appearance of fir (Abies alba Mill.) pests in the Swietokrzyskie mountains. pp. 29-38 in Proceedings of the 3rd Symposium on the Protection of Forest Ecosystems. Warsaw Agricultural University, Warsaw, Poland.

Géraud, D., Cornic, J.F. \& du Merle P. (1987) Observations sur la distribution spatiale et sur la mesure des populations pré-imaginales de la tordeuse du sapin. 1. Exposé des méthods. Les populations d'oeufs. Journal of Applied Entomology 103, 258-278.

McGugan, B.M. \& Coppel, H.C. (1962) Biological control of forest insects 1910-1958. Technical Communication Commonwealth Institute of Biological Control No. 2, 35-210.

Mills, N.J. (1983) Possibilities for the biological control of Choristoneura fumiferana (Clemens) using natural enemies from Europe. Biocontrol News \& Information 4, 103-125.

Mills, N.J. (1990) Are parasitoids of significance in endemic populations of forest defoliators? Some experimental observations from gypsy moth, Lymantria dispar (Lepidoptera: Lymantriidae). pp. 265-274 in Watt, A.D., Leather, S.R., Hunter, M. \& Kidd, N.A.C. (Eds) Population dynamics of forest pests. Andover, UK, Intercept Press.
Nealis, V. (1987) The number of instars in jack pine budworm, Choristoneura pinus pinus Free. (Lepidoptera: Tortricidae), and the effect of parasitism on head capsule width and development time. Canadian Entomologist 119, 765-771.

Sanders, C.J., Stark, R.W., Mullins, E.J. \& Murphy, J. (1985) Recent advances in spruce budworm research. 527 pp. Ottawa, Canadian Forestry Service.

Schimitschek, E. (1936) Das Massenauftreten des Tannentriebwicklers Cacoecia murinana HB. in Niederosterreich 19291934. Zeitschrift für angewandte Entomologie 22, 563-602.

Suzuki, S. (1981) Distribution patterns of larvae of Choristoneura diversana Hübner and four other tortricids injurious to Todo-fir, Abies sachalinensis Masters. Journal of Applied Entomology and Zoology 25, 1-9.

Vinson, S.B. (1986) The behaviour of parasitoids. pp. 417-469 in Kerkut, G.A. \& Gilbert, L.I. (Eds) Comprehensive insect physiology, biochemistry and pharmacology. Oxford, Pergamon Press.

Wiackowski, S.K. (1984) The fir budworm in the Swietokrzyskie mountains, its biology, ecology and control. $125 \mathrm{pp}$. Warszawa, Polish Scientific Publishers.

Xu, Y.X. \& Liao, X.C. (1985) A preliminary study of Choristoneura metasequoiacola Liu on a fossil tree. Scientia Siloae Sinicae 21, 396-403.

Zwölfer, H. (1956) Zur Kenntnis der Parasiten des Tannentriebwicklers, Choristoneura murinana $(\mathrm{Hb}$.$) . Zeitschrift für ange-$ wandte Entomologie 37, 387-409.

Zwölfer, H. (1961) A comparative analysis of the parasite complexes of the European budworm, Choristoneura murinana (Hub.), and the North American spruce budworm, C. fumiferana (Clem.). Technical Bulletin Commonwealth Institute of Biological Control No. 1, 1-162.

(Accepted 30 April 1991)

(C) C.A.B International, 1991 